\title{
Measurement of Pyuria in Urinary Tract Infections
}

\author{
I. B. HOUSTON \\ From the Department of Child Health, St. Mary's Hospital, Manchester
}

The value of pyuria in the diagnosis of urinary tract infection is related to the accuracy and reliability of the technique by which it is assessed. Two methods are widely used for this purpose, centrifugation of the urine with an estimate of the number of pus cells 'per high-power field', and an actual count of the pus cells in uncentrifuged urine in a counting chamber. It is not the purpose of this paper to compare the relative importance of pyuria and bacteriuria in the diagnosis of urinary infection, but only to evaluate the two techniques used to measure pyuria in this circumstance. Stansfeld and Webb (1953), Linneweh (1958), and Zapp and Jung (1963) all made this comparison and obtained different results. Pryles and Eliot (1966) found the discrepancy so great that they concluded that... 'satisfactory correlation was not possible'. These results prompted a further assessment of this unsatisfactory situation.

\section{Materials and Methods}

Examination was made in duplicate of 406 specimens or urine, without foreknowledge of the result of the alternative technique. The measurements were always completed within 2 hours and the majority within about 30 minutes. Uncentrifuged cell counts were performed by the author, and centrifuged estimates by several members of the laboratory staff. This factor should be borne in mind when considering the results.

Pus cell counts were performed on fresh uncentrifuged, well-mixed urine in a Fuchs-Rosenthal counting chamber (Houston, 1963). The result was expressed as pus cells/cu.mm. of uncentrifuged urine.

5-10 ml. of each specimen of urine was then centrifuged in a $10 \times 1.2 \mathrm{~cm}$. tube at $2000 \mathrm{r.p} \mathrm{m}$. for 5 minutes round a circle radius $16.5 \mathrm{~cm}$. (to the bottom of the bucket). The supernatant fluid was decanted and the cellular sediment resuspended in whatever fluid remained. The resuspended cells were tapped on to a slide and covered by a $2 \mathrm{~cm}$. square coverslip. using a $\times 63$ objective and $\times 12.5$ eyepiece, the number of pus cells in a number of separate 'high-power fields' was estimated and the result expressed as 'pus cells per high-power field' (h.p.f.).

Bacterial counts were performed either by the pour

Received February 31969. plate technique (Kass, 1956) or by the 'standard loop' technique of Hoeprich (1960). In the latter case the results were verified periodically by comparison with those of the more accurate pour plate method.

\section{Results}

In all, 406 specimens were submitted to duplicate analysis. Fig. 1 compares the results obtained on individual specimens by the two techniques.

Of the 406 specimens, 41 contained $>100$ pus cells/cu.mm. but less than 5 pus cells per h.p.f. in the centrifuged deposit; 29 of these $(71 \%)$ contained $>10^{5}$ bacteria $/ \mathrm{ml}$. in addition.

Fig. 2 shows the results of 54 separate pus cell counts on 11 specimens of uncentrifuged urine. $50(93 \%)$ of these counts were within $\pm 25 \%$ of the individual mean for the specimen.

\section{Discussion}

More than 100 pus cells/cu.mm. of uncentrifuged urine represents gross pyuria; normal urine rarely contains $>10$ pus cells/cu.mm. (Stansfeld and Webb, 1953; Linneweh, 1957, 1958; Stansfeld, 1962; Zapp and Jung, 1963; Houston, 1963; Braude et al., 1967).

On the basis of these reports the uncentrifuged pus cell counts were grouped into three categories: $>100$ /cu.mm. abnormal; 11-100/cu.mm. doubtful, probably abnormal; 0-10/cu.mm. normal. Using the centrifugation technique; 5 or more pus cells per h.p.f. are generally accepted as significant (Kass, 1956; Pryles, 1960; Riley, 1964; Kunin, Deutscher, and Paquin, 1964), but some authors accept only 10 or more pus cells per h.p.f. (Jackson, Grieble, and Knudsen, 1958). Accordingly 4 groups of results have been demarcated; no pus cells seen, normal; 1-4 pus cells per h.p.f., doubtfully significant; 5-9 pus cells per h.p.f., abnormal; 10 or more pus cells per h.p.f., grossly abnormal. Fig. 1 shows a general correlation between the two sets of results, but also some considerable discrepancies. A report of 1-4 pus cells per h.p.f. in the deposit can represent a number of pus cells varying from the undoubtedly normal to the frankly abnormal. Moreover, among those urines with $>100$ pus 


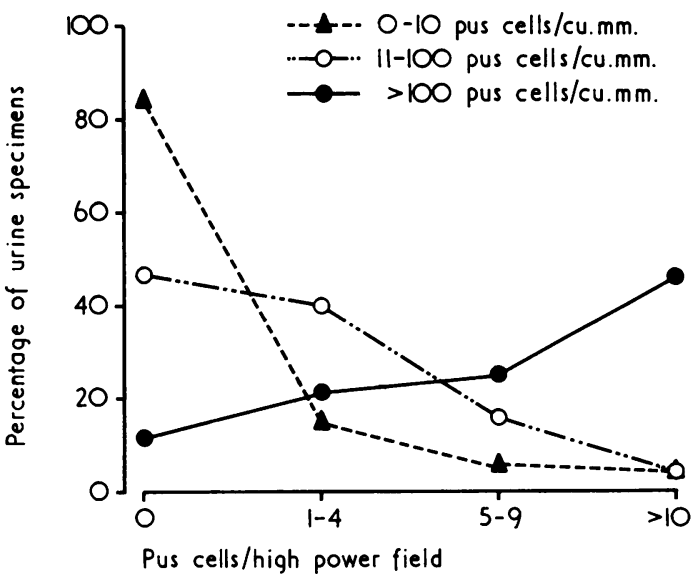

FIG. 1.-Pus cell counts per cu.mm. on uncentrifuged urine divided into three groups: 0-10/cu.mm. (104 specimens), 11-100 (168 specimens), >100 (134 specimens) compared with the results for centrifuged urine, expressed as pus cells/high power field.

cells/cu.mm. (uncentrifuged), $20 \%$ were found to have 1-4 pus cells per h.p.f. in the deposit-and $10 \%$ had none at all. This represents nearly one-third of false negatives if the uncentrifuged pus cell count is accepted as correct.

Multiple uncentrifuged pus cell counts on the same urine specimen yielded results that were within $25 \%$ of the mean value for each specimen in $93 \%$ of instances; Gadeholt (1964) found only a $10 \%$ difference between duplicate counts using a similar technique. By contrast, centrifuging the urine introduces a large number of variables. The speed of revolution and the radius of the centrifuge head, the care with which the supernatant fluid is decanted, the means of transfer of the resuspended cells to the microscope slide, the weight and size of the coverslip, and the size of the "high power field' observed must all be controlled to achieve reproducible results (Gadeholt, 1964). With initial care and continuing vigilance some of these factors can be controlled, others cannot: for example, pouring the resuspended cells from tube to slide caused a tenfold variation in measured cell concentration in the same specimen; pipetting the specimen on to the slide permitted a threefold variation. These results strongly suggest that centrifuged estimates are more liable to experimental error, especially when several different technicians are involved, than are uncentrifuged counts.

In all, 41 urine specimens contained $>100$ pus cells/cu.mm. (uncentrifuged). but $<5$ pus cells per h.p.f. (centrifuged), and of these 29 contained

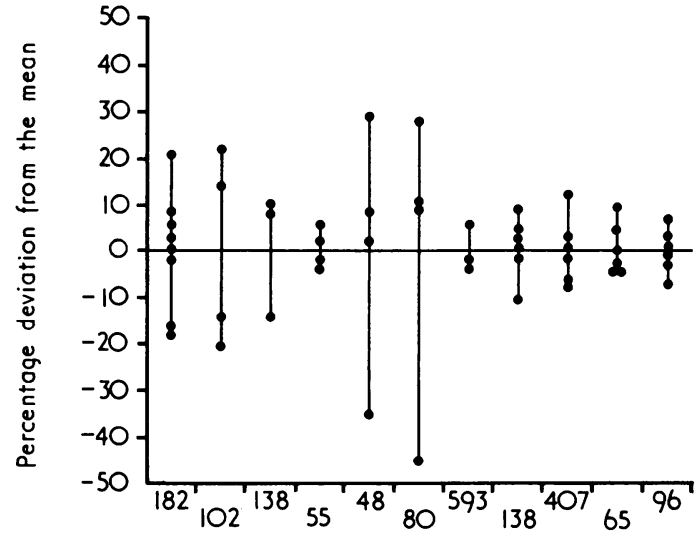

Pus cells/cu.mm. meon

FIG. 2.-Repeated uncentrifuged pus cell counts on individual urine specimens. 50 of 54 results are within $\pm 25 \%$ of the individual mean of the urine specimen.

$>10^{5}$ bacteria $/ \mathrm{ml}$. on culture. If positive bacterial culture be regarded as an independent indication of urinary tract infection, then these figures favour the use of uncentrifuged urine when using pyuria to indicate urinary infection. The Table summarizes other reports where bacteriuria has been related to pyuria, as measured in centrifuged and/or uncentrifuged urine. The results clearly show a better correlation of bacteriuria with pyuria when the latter is measured in uncentrifuged urine-best illustrated by the results of Pryles and Eliot (1966).

\section{TABLE}

Relation of Pyuria, as Measured in Centrifuged or Uncentrifuged Urine, to Bacteriuria

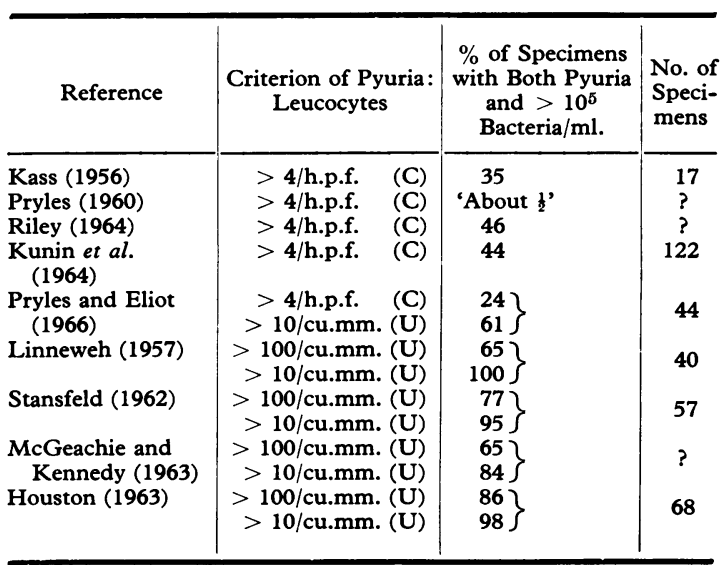

C, leucocytes per high-power field in centrifuged urine deposit. $\mathrm{U}$, leucocytes per cu.mm. in uncentrifuged urine. 
When measures of pus cell concentration yield equivocal results, an estimate of the white cell excretion rate has been recommended (Osborn and Smith, 1963; Kennedy, Ormonde, and Murdoch, 1964; Fairley and Barraclough, 1967). However, in only a minority of cases of urinary tract infection is this diagnostic refinement required, for in most cases leucocyte concentrations are unequivocally increased.

While accurate bacterial counting is probably the best single means for diagnosing urinary tract infection, an accurate pus cell count on uncentrifuged urine makes a useful contribution in most cases. That the sedimentation of leucocytes is an inadequate method (Linneweh, 1958) is a view supported by many authors (Stansfeld, 1962; McGeachie and Kennedy, 1963; Osborn and Smith, 1963; Pryles and Eliot, 1966), yet the centrifuged deposit is still widely used: the present observations provide further evidence for its abandonment.

\section{Summary}

Duplicate examinations of 406 urine specimens using two different techniques for assessing pyuria are reported. It is concluded that the use of centrifugation should be abandoned in favour of cell counts performed on uncentrifuged urine in a counting chamber.

My thanks are due to Professor W. F. Gaisford, Professor J. A. Davis, and Dr. H. B. Marsden for their advice and to Dr. R. G. W. Ollerenshaw of the Department of Medical Illustration, Manchester Royal Infirmary, for the figures.

\section{REFERENCES}

Braude, H., Forfar, J. O., Gould, J. C., and McLeod, J. W. (1967). Cell and bacterial counts in the urine of normal infants and children. Brit. med. F., 4, 697.

Fairley, K. F., and Barraclough, M. (1967). Leucocyte-excretion rate as a screening test for bacteriuria. Lancet, 1, 420.

Gadeholt, H. (1964). Quantitative estimation of urinary sediment, with special regard to sources of error. Brit. med. F., 1, 1547.

Hoeprich, P. D. (1960). Culture of the urine. F. L.ab. clin. Med., $56,899$.

Houston, I. B. (1963). Pus cell and bacterial counts in the diagnosis of urinary tract infections in childhood. Arch. Dis. Childh., 38,600 .

Jackson, G. G., Grieble, H. G., and Knudsen, K. B. (1958). Urinary findings diagnostic of pyelonephritis. F. Amer. med. Ass., 166, 14.

Kass, E. H. (1956). Asymptomatic infections of the urinary tract. Trans. Ass. Amer. Phycns, 69, 56.

Kennedy, W. P. U., Ormonde, N. W. H., and Murdoch, J.McC. (1964). Urinary cell excretion in the diagnosis of pyelonephritis. Brit. F. Urol., 36, 354.

Kunin, C. M., Deutscher, R., and Paquin, A., Jr. (1964). Urinary tract infection in school children: an epidemiologic, clinical and laboratory study. Medicine (Baltimore), 43, 91.

Linneweh, F. (1957). Zur Klinik der Harnwegsinfektionen. II. Neuere Kriterien zur Diagnostik der Harnwegsentzündungen. Dtsch. med. Wschr., 82, 438.

- (1958). Quantitative Diagnostik und Therapie-kontrolle der Harnwegsentzündungen. Z.Kinderheilk., 81, 567.

McGeachie, J., and Kennedy, A. C. (1963). Simplified quantitative methods for bacteriuria and pyuria. f. clin. Path., 16, 32.

Osborn, R. A., and Smith, A. J. (1963). A comparison of quantitative methods in the investigation of urinary infections. ibid., $16,46$.

Pryles, C. V. (1960). The diagnosis of urinary tract infection. Pediatrics, 26, 441.

—, and Eliot, C. R. (1966). Pyuria and bacteriuria in infants and children. Amer. F. Dis. Child., 110, 628.

Riley, H. D., Jr. (1964). Pyelonephritis in infancy and childhood. Pediat. Clin. N. Amer., 11, 731.

Stansfeld, J. M. (1962). The measurement and meaning of pyuria. Arch. Dis. Childh., 37, 257.

—, and Webb, J. K. G. (1953). Observations on pyuria in children. ibid., 28, 386.

Zapp, E., and Jung, B. (1963). Untersuchungen zur zytologischen und bakteriologischen Harnwegsdiagnostik im Kindesalter. Med. Mschr., 17, 485. 